\title{
FRĂMÂNTĂRILE OMULUI CREATOR ÎN „TINDA ÎNFĂPTUIRII”. MEŞTERUL MANOLE LA LUCIAN BLAGA ŞI VALERIU ANANIA
}

Florina-Maria Andercău

florina.andercau00@e-uvt.ro

Universitatea de Vest din Timișoara

\begin{abstract}
For a vast period of the human history, the whole universe has been perceived as creation. In a created cosmos people create following the example of divinity and "any creation has a model: the way in which gods created the Universe" (Eliade, Sacrul și profanul 25). Lucian Blaga illustrated this fact in one of his poems in his unique manner: "Through all eras/ what a clod in torment!/ Under all spheres/ Everything begets" (Through all eras, $t$. $n$.). Creation is the wonderful constant of existence through aeons. This paper will analyse how the creator's condition is unfolded in two dramatic texts which belong to different literary periods of Romanian literature: Meșterul Manole by Lucian Blaga and Meșterul Manole by Valeriu Anania.
\end{abstract}

Key words: creation, destiny, love, Master Manole, sacrifice.

„Purces-am în lume/ pe punți de baladă...”

(Cântăreți bolnavi, Lucian Blaga)

Impulsul creator are motivații profunde, resorturi ce se regăsesc în însăși umanitatea noastră. Lumea, ca aglomerare de fapte concrete, nu a fost niciodată în măsură a satisface „,capacitatea existențială a omului” (Blaga 167): „A exista ca om înseamnă din capul locului a găsi o distanţă faţă de imediat prin situarea în mister. Imediatul nu există pentru om decât pentru a fi depășit. Imediatul există pentru om numai ca pasaj. Ca simptom al unui altceva, ca signal al unui dincolo” (Blaga 168-169). Această situare privilegiată are și consecințe pe măsură: „Situarea în mister, prin care se declară incendiul uman în lume, cere o completare; situației îi corespunde un destin înzestrat cu un permanent apetit; nevoia de a încerca o revelare a misterului. Prin încercările sale revelatorii omul devine însă creator, și anume creator de cultură în genere" (Blaga 169). „Existența în orizontul misterului și în vederea revelării” (Blaga 175) este un dat fundamental, intrinsec ființei umane, căreia i se oferă două modalități de revelare: actele de cunoaștere și cele plăsmuitoare (Blaga 176). Blaga formulează tranșant esența acestei condiții: „Pentru a fi creator de 
cultură, omul nu trebuie să fie decât om, [...] o ființă care dă urmare unui destin înscris în structura sa" (177).

Cu toate că actul creator este, ,înscris”, pecetluit în structura sufletească a omului, el nu se realizează facil, fără anumite sacrificii: „Crearea culturii cere câteodată negrăite jertfe: ea ucide și devastează. Creația își are pârjolul ei” (Blaga 170-171). Un pârjol care cuprinde atât creatorul, cât și ființele și lucrurile aflate în proximitatea lui, sau, cum ar spune Blaga, referitor la ,patima clădirei” - ,patima aceasta coborâtă de aiurea în om e foc ce mistuie preajmă și purtător. Și e pedeapsă și e blestem”. Acest fapt este bine ilustrat într-unul din miturile fundamentale ale culturii române, mitul jertfei pentru creație. Mitul Meșterului Manole este „mitul estetic, indicând concepția noastră despre creație, care e rod al suferinței” (Călinescu 42). Pentru a înțelege modul în care acest mit va fi prelucrat în literatură de cei doi autori pe care îi avem în vedere, Lucian Blaga și Valeriu Anania, trebuie să explorăm tărâmul creației populare în care el a fost valorificat în balade. În fond, mitul și balada se referă la faptul că, pentru ca o creație să dureze, ea trebuie să fie însoțită de un sacrificiu sângeros (Eliade, De la Zamolxis 192). Explicația ar fi că ,pentru a dura, o construcție (casă, lucrare tehnică, dar și operă spirituală) trebuie să fie animată, adică trebuie să primească în același timp viață și suflet. Transferul sufletului nu este posibil decât pe calea unui sacrificiu; în alți termeni, printr-o moarte violentă” (Eliade, 193-194). Starețul Bogumil dă glas acestei idei în piesa blagiană - ,sufletul unui om clădit în zid ar ține laolaltă încheieturile lăcașului până-n veacul veacului!" ( $L B$ 147), în timp ce în scrierea lui Valeriu Anania meșterii vin cu propunerea, iar Manole o formulează explicit: „Nu vom putea sfârși o frumusețe/ De nu sfârșim într-însa și un dor!’. Această concepție își are originea în miturile cosmogonice, care explicau crearea Universului prin uciderea unui uriaș (Eliade, 195).

Dacă uciderea unei ființe este procesul violent și dureros menit să asigure trăinicia construcției (materiale sau spirituale), jertfa pentru creație mai implică o latură, ce de această dată vizează creatorul. El este supus unor presiuni și frământări continue, căci „Marele Anonim a înzestrat pe om cu un destin creator, dar prin frânele transcendente el a luat măsura ca omul să nu i se poată substitui”, tocmai pentru a-1 menține ,în permanentă stare creatoare” (Blaga 182). Această necurmată limitare, în care omul creator întâlnește pretutindeni bariere trasate de Creatorul Absolut, ,împrumută destinului creator al omului o înfăţișare tragică și magnifică în același timp” (Blaga 194). Soarta „scafandrilor misterului” (ca să preluăm o inspirată formulare a lui Valeriu Anania) e îngemănată cu suferința, cu zbaterea, cu un zbucium incandescent care nu îngăduie nici pacea, nici odihna. Acest fapt este sugestiv zugrăvit în poemele blagiene: „Mistuiți de răni lăuntrice 
ne trecem prin veac” (Noi, cântăreții leproși), „Răni ducem - izvoare - /deschise subt haină” (Cântăreți bolnavi), „Prin suferinți, dintr-un loc într-altul, prin arderi/ ne purtăm îndoielnică firea” (Atotștiutoarele) și exemplele pot continua. După cum se poate observa, creatorii se învârt într-un univers al rănilor, al suferințelor, al arderilor, care, deși constituie izvoare, surse ale cântecului poetic, lasă totuşi urme adânci.

Mitul Meșterului Manole și mai ales prelucrările lui literare au particularitatea de a unifica aceste două perspective asupra jertfei și asupra suferinței creației. Pornind de la premisa că orice creație presupune o jertfă a unei ființe vii, mitul în discuție face ca tocmai cea mai dragă ființă a creatorului să trebuiască să fie sacrificată. La conștientizarea oricum tragică a jertfei vieții se adaugă durerea iubirii sacrificate, la suferințele inerente ale creatorului se alătură sfâșietoarea durere a pierderii absolute. Avem aici de-a face cu o contopire a creației și a suferinței fără margini, ale căror planuri se întrepătrund până la confundare în conștiința creatorului. Procesul creator este astfel devastator pentru Manole: „Meșterul Manole și-a zidit soția sub pietre și var, pentru ca să înalțe biserica. Surprindem gâlgâind în această legendă ecoul crud al conștiinței sau al presimțirii că o creație trece peste vieți și devastează adesea chiar pe creator. [...] Se creează cu adevărat cel mai adesea numai la înalte tensiuni, cărora organele de execuție nu le rezistă totdeauna. Creația sfarmă adeseori pe creator" (Blaga 170-1).

Comparația se realizează între un text în proză și unul în versuri, însă la fel de poetice, căci teatrul blagian a fost „de la început apreciat ca un teatru poetic”, impunându-se ca ,poezie” (Todoran 97). Eugen Todoran susţine că „drama omului cuprins de patima frumosului ia forma poeziei în cel mai autentic spirit al tradiţiei folclorice, în care mitul este una din cele mai vechi încercări de revelare a misterului prin îmbogățirea faptelor istorice în conținutul lor uman” (98). Într-un astfel de text dramatic, ,personajul, ca element ideatic, este factorul-cheie” (Cubleșan, Lucian Blaga 9). Se remarcă la personajele blagiene perspectivele unei vieți ,,intense, tragice”, întro ,prelungire a vieții omului pe dimensiunea eternității, simțită ca o realitate de cel ce se proiectează pe el însuși în centrul lumii, făcând din întreaga lume un cadru al dramei lui însuşi”, (Todoran 11). După drama lui Blaga, Meșterul Manole de Valeriu Anania este ,piesa cu cea mai mare tensiune dramatică” (Micu 234), antrenând de asemenea personaje care impresionează prin forța și complexitatea lor. Cum ,nicio suferinţă nu-i așa de mare/ să nu se preschimbe în cântare” (Catren, Lucian Blaga), vom urmări modul în care drama interioară a ființei creatoare este sublimată în operele avute în vedere, într-un plan de sinteză a poeticului cu spectacularul. 
„Mă mântui prin tine cu dulce minune..."

(Axion, Valeriu Anania)

Pe ,schelele minunii”, trupul creatorului rămâne în plan secund. Nevoile fiziologice par a fi ignorate, toată atenția îndreptându-se asupra creației. Hrana este cea dintâi de care el se poate lipsi: munca se realizează ,,întruna, fără întrerupere. Fără apă, făă pâne” ( $L B$ 216), căci „de ea (de mănăstire, n.n.) acum mi-i foame și mi-i sete!” (VA 74). Mira, văzându-i pe lucrători, nu poate să nu remarce „mortificarea” acestora: „tot a pierit din oasele voastre: carne, lumină, suflet și voinicie” (LB 195). Privind retrospectiv, Manole își dă seama cu regret care a fost de fapt „nutrimentul” imaterial al prăbușirii lui: „sufletul a băut fapte și povești amare” (LB 209). Munca și speranțele au compensat postul negru al trupului, alimentându-i și menținându-i energia necesară creației. Gustul amar al suferinței va fi totuși omniprezent, și, după cum se va putea observa, evoluția subiectului operelor va corespunde unei involuții a laturii umane a creatorului, având de-a face în esență cu o istorie a năruirii.

O perspectivă interesantă este aceea a lipsei somnului, de care creatorul se face ,vinovat”. Când Mira îi spune cu îngrijorare că pierde prea mult somn, Manole răspunde cu o replică în care îl situează pe ultima poziție, sugerând cât de puțină importanță acordă acestei pierderi: „De șapte ani pierd credință, pierd ziduri, pierd somn" ( $L B$ 154). Abia după credință și ziduri, aceste cruciale elemente ale universului creatorului, vine și somnul. Mira ajunge să îl numească „inimă fără odihnă, gând treaz, visare fără popas" ( $L B 154)$, mutând accentul pe cauza (o inimă zbuciumată) și pe consecințele (predispoziția spre reverie, gândurile plăsmuitoare) acestei stări de veghe continue. „Gândul treaz” se frământă pentru a născoci un alt fel de vis decât cel de noapte. Pentru creatori, nopțile sunt „zămislitoare” (VA 39). Nu e întâmplător că în ambele cazuri viziunile operelor prind contur în „taina miezului de noapte/ Când visu-i abur și se face chip” (VA 214). Când pentru restul lumii întunericul e mut și echivalent cu somnul simțurilor, pentru sufletul creator el potențează misterele și excită acuități de altă natură. Pentru ceilalți contururile se dizolvă, pentru creatori ele abia se nasc. Ochii lor lăuntrici spintecă întunericul și nedeterminarea, dând forme gândurilor ce se vor concretiza în opere. Ei captează imaginile pe care le pictează lumina selenară pe pânze de gând. E aici sugerată o diferență remarcabilă între cei posedați de patima creației și restul oamenilor. Frunțile care sub solicitanta povară a gândurilor par a nu se mai netezi niciodată ,ard” nopțile între planuri și idei, făcând acei pași spirituali în plus față de restul lumii, ca singură modalitate de a o depăși. Unde și când oamenii obișnuiți se opresc, geniul continuă fără odihnă pentru a accede la orizonturi mai înalte. 
Măreția viziunii are nevoie însă și de muncă fizică pe măsură. Zidarii recunosc că mâinile lor „,nu mai sunt mâini de om”, au ,,pielea tăiată de brazde cu suc roșu”, fiind „,mâncați de var până la oase” (LB 169). Deși aceste imagini vizuale constituie un spectacol greu de privit din exterior și demoralizator pentru actanți, Manole răspunde necruțător oricăror lamentări: „,Ne-am îndoit până acum trupurile, ne-am întins și ne-am zbătut în soare, dar n-am ajuns încă la marginea puterii noastre. Din aiurare și din trupuri slăbite și mai mult se poate stoarce.” (LB 178). Limitele obișnuite sunt transgresate. Munca trebuie realizată chiar și dincolo de luciditate și de epuizare. În ochii privitorilor, meșterii zidesc „năuci, nebuni” (VA 89), dar ca niște „,nebuni de frumusețe” ( $V A$ 34). Aceste eforturi supraumane au consecințe cu dublu sens. Chiar dacă zidarii sunt epuizaţi fizic, ei „,cresc” spiritual „odată cu piatra” (VA 79). Trupurile sunt zdrobite, dar mănăstirea, această minune „de slavă grea și vie” ( $V A$ 9), ,se înalță și durează” ( $V A$ 94) și sufletele urcă treptele desăvârșirii artistice.

Lipsa hranei, a somnului, munca supraomenească, toate acestea cultivate din principiu, pot să indice faptul că piesele ,statuează dramatic o filosofie a înfrânării, a mortificării, o concepție ascetică a actului de creație" (Micu 231). Meșterul Manole al lui Anania îi pune pe zidari să facă un jurământ foarte similar celor călugărești: „,Slujbă cu credincioșie!/ Gând țesut în faptă vie!/ Ascultare-n ce se cere!/ Muncă, taină și tăcere!/ Legământ cu locul muncii!/ Neprihană-n trup, ca pruncii,/ Și curați la gând, ca mirii,/ Cât stă cumpăna zidirii!” (VA 28). Fiecare cerinţă este formulată imperativ, arătând importanța coordonării între asceza trupului și integritatea minții „,vii”, „,născocitoare”, capabile de a realiza „zidire curată”. Creaţia este, în esență, o reflectare a spiritului creator, însă, pentru că în cazul de față ea este o ofrandă adusă divinitățiii, se impune și acest deziderat al purității fizice.

Extinzând perspectivele dincolo de învelișul carnal al creatorului și implicaţiile acestuia, discuția se poate îndrepta către regiunile de profunzime ale subiectului, unde frământările capătă un caracter întru totul dramatic. Situându-ne în paradigma blagiană, omul este ,menit creației cu orice risc” (Blaga 186), iar cultura (percepută ca sumă a creaţiilor spirituale) e ,aşa de mult împlinirea omului, încât acesta nici nu are posibilitatea de a o nega cu adevărat și efectiv, chiar dacă ar fi convins de inutilitatea și primejdiile ei” (Blaga 171). Patima creatoare este înțeleasă în ambele piese drept un impuls transmundan căruia nu i te poți împotrivi. Ea e „duhul, care dinăuntru te împinge să clădești” ( $L B$ 174), „dorul de a zămisli frumusețe” ( $L B$ 232), acel dor dătător de noimă din poeziile blagiene (,Cu dorul tău începe noima ta”, Odă către runa), sau vis înrobitor (,visuri ce ți se dau și nu le-alegi”, Prolog), obsedant: ,...Că eu pace/ Nu voi avea decât în clipa 
când/ O voi vedea din visul meu zburând/ Ca o minune albă către cer" (VA 11). Creatorii se simt robii unei voințe mai mari și mai puternice decât ei, căreia nu i se pot împotrivi. Mai ales în creația blagiană, motivul predestinării e recurent: ,suntem oare noi chemați să judecăm ceea ce mai presus de vrerea noastră prin noi se face?” ( $L B 174)$; ,un destin se împlinește în noi? Încet, sigur, și fără abatere? Răscoala noastră de râs scoate doar mușuroaie de soboli în drumul dinainte împlinit al sorții!” (LB 173); ,,prin ițele vrerilor noastre o altă vrere cu mult mai mare se țese, singură, trudnică, puternică și neînțeleasă” ( $L B$ 180). În piesa lui Anania, Iovanca e cea care exprimă această idee, a unei Voinţe absolute care dictează deciziile muritorilor mai presus de înţelegerea lor: „,sunt porunci/ Pe care le-mplinești făr' să le știi” (VA 68). Creatorii își asumă patima creatoare, „dar o și înțeleg ca fiind coborâtă din neant în sinele individului” (Bâgiu, Manole 235). Acest mod de a înţelege lumea și, în special, creația, acordă întregii discuții o notă tragică.

Pentru creatori este dureros faptul că, deși împlinesc un destin dictat de Divinitate și pentru slava ei, se simt părăsiți („Doamne, Doamne, de ce m-ai părăsit?” ( $L B$ 145), „unde-i Zidarul cel mare?” (LB 150)), nedreptățiţi: „Că suntem drepți și ni se răspunde strâmb. Și fără nădejde suntem ținuți în tinda înfăptuirii” ( $L B$ 148). Știind că i se cere o jertfă, Manole este ,surprins zbătându-se între două zădărnicii, a incapacității de a-și asuma, deocamdată, decizia, dar și a conștientizării absenței, prin tăcere, a transcendentului” (Bâgiu, Manole 226). Acest sentiment al abandonului este resimţit acut de creatorul care se crede în slujba Divinităţii - „niciun har nu vine, fremătând,/ Nu, niciun har cu focul zămislirii...” (VA 39); „Cer har de sus, și har de sus nu vine...” (VA 40). Mira surprinde extrem de sugestiv condiția în care se aflau: „Parcă Dumnezeu s-a întors acum cu spatele către noi și stăm în umbra lui. Și nu mai știm ce este, și nu mai știm încotro” ( $L B$ 197). Această tăcere paradoxală a divinității seamănă cu cea evocată adeseori de Blaga în poeziile sale, de exemplu în Psalm - „(Doamne) Ești muta, neclintita identitate” - sau în Noi, cântăreții leproși: „Pentru noi cerul e zăvorât și zăvorâte sunt și cetățile”. De la această nostalgie după ajutorul divin în care credeau, zidarii trec printr-o fază de neutralitate și confuzie - trebuie să înalțe niște ziduri „pe care nici dracul nici cerul nu le vrea” ( $L B$ 193) -, ca apoi să ajungă la revoltă - ,cui nu i se răscoală sângele gândindu-se că munca a fost în deșert?” ( $L B$ 177) - și la îndoială în infailibilitatea divinității - ,singura mărire îndoielnică e numai a Celui-de-Sus” ( $L B$ 173). Manole ajunge chiar în punctul de a blestema totul, în adâncurile disperării - „Blestemat să fie - blestemat - blestemat!” ( $L B$ 156) - și de a strânge amenințător pumnul ,împotriva credinței (de) astăzi și totdeauna” ( $L B$ 232). Revolta se transformă spre finalul piesei în negarea oricărui sentiment pozitiv față de divinitate: „Manole nu iubește cerul. Și îngerii-i fac rău, fiindcă Manole a pierdut tot” ( $L B$ 217). 
Speranțele zidarilor se estompează gradual, de la credința într-un ajutor divin, la neutralitate, ca apoi concluzia să se ivească logic, dureros: de fapt, „Satan e/ Stăpân aici, şi iadul” (VA 218).

Tema (absenței) norocului este extensiv dezvoltată în opera blagiană, întrucât ideea divinităţii (de orice fel) este mai estompată. „Meșterul Nenoroc” își înfăptuiește creația sub o boltă în care „„ăsare o zodie nebună” și „,norocul apune” ( $L B$ 144). Ea e ,închipuită în ceas orb”, de aceea „întrece puterile” ziditorilor ( $L B$ 172). Însuși dezechilibrul existențial iscat de moartea Mirei este pus pe seama lui: „Cumpăna voastră nu se mai clatină. Limba stă neclintită. Numai stânga cântarului meu cade-n prăpastie fără fund. Încă o dată a hotărât nenorocul” ( $L B$ 203). În finalul piesei, când trebuie să-i spună lui vodă ce anume l-a adus în condiția aceea deplorabilă, el afirmă: „suflarea aceea nu are nume, dar dacă vrei, îi poți spune fără sărbătoare și fără noroc” (LB 231). $\mathrm{Cu}$ alte cuvinte, jocul nefast al sorților este responsabil de năruirea lui, nu capriciile unor demoni ca la Anania.

În ceea ce privește obstacolele puse în calea creației, ambele situații par o luptă continuă între creatori și niște forțe extramundane care sunt greu de identificat de actanți: „Meșterul pare a se afla în conflict deschis și continuu cu toate puterile și dimensiunile ființării care îi zădărnicesc propria înfăptuire” (Bâgiu, Manole 225). Primele bănuieli sunt că zidurile ar fi dărâmate de ,puteri fără grai”, ,puteri nebotezate și fără de nume” (LB 146), ,măiestriile sătănii”, „,dihonii”, ,zâzanii” (VA 85), variante ale unor forțe demonice rău-voitoare. Dacă în piesa blagiană această ipoteză a unor puteri „mai mari decât morții răi” ( $L B$ 146) pare a fi aproape unanim acceptă, la Anania e reprimată imediat și categoric: „Noi între noi cătăm o rădăcină/ Nenorocirii” (VA 89). Acestea sunt și liniile directoare ale sensurilor celor două piese: la Blaga, forțele contrare vor fi mereu nedefinibile și în afara oricăror semnificații religioase; la Anania, omul se află în luptă cu avatarurile Satanei sau cu răul din el, înțeles tot în sens creștin, ca sămânță a diavolului. O privire mai atentă asupra nuanțelor relevă însă un fapt întru totul interesant referitor la planul în care se situează „puterile” blagiene. Când Bogumil încearcă să le plaseze într-un context, el afirmă: „Nu e apă și nu e foc - sunt puterile! Ele disprețuiesc întinderea locului și ies când vor de subt legile vremii. Le crezi aici, și ele din întâia beznă răspund. Le crezi acolo, și ele dănțuiesc cu înfricoșare in noi" (LB 145). Mai exact, tot în planul interiorității se situează și ,inamicii” blagieni, chiar dacă într-o altă paradigmă. Sensurile celor două piese se întâlnesc din nou sub zodia aceluiași dușman pe care creatorul trebuie să-l învingă și să-1 supună: propriul sine. „Armele” vor fi într-un caz laice, în celălalt religioase, dar vrăjmașul identic, și deci, la fel de puternic. Tumultul lui e sugestiv descris de Găman: „E o învârtire. E un vârtej. Şi auie trist, cu amenințare, ca în noapte de început, ca în 
noapte de sfârșit” ( $L B$ 146). Într-adevăr, în ființa creatorului e în permanență un vârtej amețitor al ideilor, un dans dureros, dar impunător, magnific în incandescența lui. E ca ,în noaptea de început”, probabil o referire la geneza biblică, în care Cuvântul lui Dumnezeu crea în întunericul originar de dinaintea lui „Fiat lux!”: nedeterminare absolută. E ca ,în noaptea de sfârșit”, apocaliptică, cu judecăți și lupte cutremurătoare. Pe toate acestea le poartă creatorul în sine, în vârtejuri amețitoare și uneori chiar deconcertante în incoerența lor. Cu sine trebuie să se lupte și pe sine trebuie să se îmblânzească, așa încât omul să se poată împăca cu visul său (VA 350). Forța acestor ,,puteri” va trebui să dea formă pietrei, între aceste energii creatoare latente și realitate va trebui să fie Meșterul făuritor de punți, căci adeseori „Fierbe-nchipuirea,/ Se-nvolburează mâna, dar zidirea/ (Îmi) șovăien cărbune" (VA 11).

Această continuă stare beligerantă cu sinele este solicitantă și nu îngăduie bucuria, de aceea tristețea creatorilor este omniprezentă. Până la jertfă apare din cauza neîmplinirii speranțelor, după jertfă o întâlnim acutizată într-o suferință fără margini. Mai mult, amărăciunea meșterului blagian e o consecință a faptului de a fi ,veșnic la început de drum” ( $L B$ 144), a conștientizării că „se petrec lucruri necurate pretutindeni” ( $L B$ 144), a zădărniciei încercărilor: ,,a fost pretutindeni în zadar, totdeauna în zadar” (LB 175), „O, părinte, cât e de greu. Nicăiri gândul nu încetează să se frământe... Înălțarea ei veșnic întârzie și pământul se scutură. Nimic nu ajută - ce să fac? Totul a fost în zadar - ce începem? Încă de-o mie de ori, lucrare de nebun înainte îmi flutură. Până la sfârșitul zilelor încă o dată și încă o dată, de nenumărate ori în deșert și iar în deșert! Nu, din chinul acesta nu voi scăpa nici mâne, nici pomâne, și schelăria nu va rămânea în dreaptă trăinicie pentru catapeteasmă niciodată!” ( $L B$ 148). Manole ajunge să li se adreseze cu apelativul „fraţi întru tristețe” ( $L B$ 171), ea devenind, prin ubicuitate și putere de acaparare, definitorie. La Anania, tristețea absolută pare să fie aceea a „,visului prăbușit” (VA 20): „E greu,/ Jupâne Calapăr, să-nveți/ Din har să-nchipui frumuseți/ Și să descoperi într-o zi/ Că totu-i sterp, că tot ce știi/ Începe-n vânt să se deșire..” (VA 23). În final, când construcția e gata, Sfetea face un sugestiv „rezumat” al suferințelor zidirii: „În zidul ăsta, avo, e scrâșnet, e durere,/ M-auzi, părinte? Scrâșnet, nu geamăt, nu suspin!.../ În zidul ăsta, avo, e strâns atâta chin,/ Că de-aș ofta odată, tot ce auzii,/ Un vifor marear sarge tăria-n temelii,/ Și de s-ar strânge-n clipă și lacrimile toate/ Ce le văzui, în maluri o Dunăre s-ar zbate" (VA 189).

Maeștrii și zidarii, acești minunaţi „,născători de rai” ( VA 34), împărtășesc atât suferințele și tristețile, cât și privilegiile facerii, căci formează un grup bine închegat, cel puțin până la un anumit nivel. Elogiul pe care îl face Manole artiștilor e emblematic. „Lăsați pe vodă! Nu-nțelegi 
creștine,/ Că noi suntem voivozii frumuseții? / Nu știi că regii nu-s decât drumeții/ Adăpostiți în veșnicia noastră?/ Privește cerul, Dane! E albastră/ Tăria și adâncă!... Uite, nava/ Zidirii noastre cum despică slava/ Spre țărmul zării! Meșteri mari, pe ea!/ Zvârliți în slavă ancora! Să stea / Pe veci înfiptă-n creasta veșniciei!” (VA 184). Manole este totuși liderul și maestrul, cel care îi inițiază în „legea lucrului frumos”, având menirea de a-i sui „la desăvârșiri” și de a-i scoate „aur lămurit” (VA 27). Dar nu doar meșterul e obsedat de înălțarea bisericii, ci și ei mărturisesc: „,arătarea ei ne urmărește pretutindeni”, „, chipul ei ne însoțește pe tot drumul”, „Suntem bolnavi de ea. O simțim în văzduh ca o mătase. Nu e nicăiri și totuși dorul de ea - e în noi ca un dor de casă" (LB 176-7). Însă această consonanță între voințe nu durează mult. Zidarii doresc să renunțe, descurajați de nereușite: „meștere, nu mai credem nimic. Între orbi ești cel mai orb. Vei rămânea singur, cufundat în vis și vinovat. [...] Nu ne-am unit cu tine în faptă și vis? Dar acum răbdarea nu mai are din ce să se hrănească” ( $L B$ 173). Răbdarea lor și dorința de creație sunt limitate. Chiar dacă Manole a trezit în ei vocația creatoare latentă și patima creației îi definește și pe ei, „ea n-are intensitatea devastatoare pe care o cunoaște meșterul" (Gană 362). Pentru ei, lupta lui Manole cu stihiile e absurdă, de neînțeles, nebunească. Meșterul remarcă acest lucru: „de la o vreme, ca o tulbure și largă apă ne desparte...." (LB 192). E tocmai distanța de la patima creatoare autentică la simplii executanți. De aceea, Manole nu îi constrânge să rămână: „Să purceadă de aici cel ce poate! Părăsiți-mă, rămân eu! Varul mi-1 vor stinge ploile. Soarele îmi va aprinde cuptoarele. Lutul îl vor frământa copitele. Biserica voi ridica-o singur!” ( $L B$ 177). Totuși, mai regăsesc puterea pentru o ultimă încercare și maestrul nu e nevoit să clădească „în amară singurătate”. Însă jertfa cea mai mare tot lui i se cere, fapt care va lărgi ireconciliabil hăul dintre ei: „voi n-aţi pus în învingere decât cârtire, eu am pus scumpă viață!" (LB 219). În piesa lui Valeriu Anania, zidarii se sinucid împreună cu Manole, arătând o oarecare împăcare în moarte. La Blaga, după ce meșterul se sinucide, zidarii „sunt cu rostul pierdut”, înțelegând că odată ce liantul dintre ei și creație a dispărut, ei sunt meniți rătăcirii „din loc în loc” (LB 240).

Totuși, ceea ce îi mai particularizează pe cei doi maeștri este și inegalabila iubire nu doar față de creație, ci și față de soții. La Blaga, Manole o vede pe Mira drept „început și sfârșit”, „tot”, „lumina omului”, având „gust nebun de sânge și somn” (LB 156), adică tot ce are el nevoie pentru zidire. „Mira e femeia-copil, candoarea însăși, e viața pe care o iubește Manole și pe care ea o apără aşezându-se cu nevinovăţie în calea destinului pe care nu-l înțelege" (Gană 363-364). Ea va ajunge „altar viu între blestemul ce ne-a prigonit și jurământul cu care l-am învins” ( $L B$ 202). La Anania, dragostea e cea care „,̂nfăptuiește minuni” ( $V A$ 8). Manole îi cere Siminei ,izvoarele luminii” (VA 
38), căci ea e „Zămislitoarea noastră și-a harului din noi” (VA 96), ,... ea, femeia/ Ne rodnicește mintea! Că noi ce-avem? Ideea!/ Ideea însă-i stearpă fără iubire!..” (VA 95). În jurul farmecului ei gravitează creatorul însetat de inspirație: ,,.. Că mintea mi se-nvârte,/ Dar veșnic către tine-și face pârte,/ Femeie scumpă, odrăslită-n mine/ Ca apa-ntr-o fântână! [...] Știi tu? Pline/ Mi-s marginile minții de-mpânzirea/ Făpturii tale!... Iartă-mi rătăcirea!/ Te vreau și-acum în casnicul tău rost, /Iubirii strajă, minții adăpost...” (VA 151). Așa cum observa Dumitru Micu, „femeia e dragoste și cântec. Femeia declanșează în creator inspirația” (231). În piesa blagiană, „Manole nu poate înțelege viața lui fără Mira, așa cum n-o poate înțelege fără creație” (Gană 357). În opera lui Valeriu Anania, nicio „mândrețe” nu poate fi concepută ca plutind ,mai presus ca o iubire”, ba mai mult, i s-ar pierde orice înțeles: „Ce rost/ Ar mai avea mândrețea fără tine,/ Fără iubire?” (VA 108). Și totuși, nenorocul, Dumnezeu sau ,puterile” fac ca tocmai această iubire imensă să fie sacrificată în ambele cazuri, căci ,aceluia i se va lua, care mai tare va iubi” ( $L B$ 182). Bineînțeles, meșterii sunt împătimiții creației și ai iubirii și, cu ochii la „steaua răsăritului”, trebuie să facă ,jertfa cea mai mare” ( $L B$ 151), așa încât mănăstirea va fi „un cântec de iubire împletit cu un cântec de moarte” (LB 217). Jertfa este precum ceara topită pentru inima creatorului și îl face să „sângereze amar” (LB 180). Dumitru Micu deschide o perspectivă interesantă asupra sacrificiului din creația lui Valeriu Anania, care credem că se poate extinde și asupra celei blagiene: „Opera nu se lasă creată decât de acel ce i se consacră în exclusivitate. Manole, și împreună cu el ceilalți meșteri, au crezut că se pot împărți. De aceea n-au izbutit să dea trăinicie zidurilor. Creația pretinde opțiune categorică. Spiritul creator are de ales între două comori: arta și iubirea împlinită (Micu 231): „Că nimeni nu poate sluji dintr-o dată/ La două altare de dragoste-ntreagă” ( VA 81), și ,frumosul cere preț,/ Iar ce e ieftin nu e nici trainic, nici măreț’ ( $V A$ 19). Prețul a fost cel mai mare.

Pe cumpăna gândirii, iubirea și patima creatoare cântăresc în mod egal. Odată dragostea jertfită, echilibrul creatorului este distrus și începe declinul său. Vorbind pietrelor, Manole le spune: „...azi mi-am pus/ Inima și mintea-n voi!” (VA 167), adică totul. În același registru, meșterul blagian, alunecând iremediabil pe panta alienării, afirmă: „Am băut turbările jurământului, să clădim de-acum cu minţile arse. Loc, îmi trebuie loc! Nimic nu e bine. Temeliile lumii sunt fără de noimă. Când El a clădit, ce a jertfit? Nimic... A zis și s-a făcut. Și totuși mie totul mi-a cerut” ( $L B$ 219).

„Împlinit ca artist, Manole se regăsește neantizat ca om” (Bâgiu, Manole 232). Moartea iubirii îl nimicește pe creator în ambele cazuri: „Oh, parcă m-am despărțit de mâini, și trupul e undeva jos, și capul în altă parte. Sunt plin de răscoală, de somn și de moarte” ( $L B 216)$. Așa cum 
anticipa Găman, chiar dacă gândul s-a împlinit, pacea n-o mai întâlnește. Zidarul al doilea remarcă: „Meșterul nu mai găsește odihnă. Se duce în umbră. Se-ntoarce la ziduri. Se duce. Se-ntoarce. În tânguire se duce, năuc se-ntoarce” ( $L B$ 210). În creația blagiană, Manole se înstrăinează de tot ce e în jurul lui, inclusiv de el însuși: „Uită-te la mine: mai sunt eu cel ce am fost? Manole nu mai este. Privește mâinile acestea sângerate din senin, sunt ale mele? Manole a plecat. Manole nu mai este. Numai un trup a rămas aici care s-a rănit de spinii cerului” ( $L B$ 216). Într-o parte semnificativă a ultimului act Manole vorbește despre el la persoana a treia, ca despre un altul, atât de mult suferința cumplită 1-a îndepărtat de sine. El se pierde într-o uitare de sine groaznică, devine inconștient de propriile acțiuni - „din tot ce s-a întâmplat în aceste zile fără sfârșit- nimic nu știu” (LB 216) -, își uită identitatea și nu-i mai recunoaște pe zidari - „Cine sunt eu? Cine sunteți voi??” (LB 222). Când aceștia din urmă îi amintesc că și el a lucrat la zidire, el afirmă surprins: „Grozavă e această uitare în care am căzut. Și eu am lucrat? Nu! Nu se poate!” ( $L B$ 216) Mai mult, zidarul al treilea îi spune că a lucrat „zi și noapte, cu glas ridicat și cu hohot” ( $L B$ 215), ceea ce evocă acel tip de dureri ale universului blagian care „nu sunt adânci decât atuncea când râd” (Veniți după mine, tovarăși). Credem că este edificatoare pentru a înțelege sciziunea din sufletul creatorului replica pe care o dă Manole atunci când i se spune că el a fost cel care a zidit-o pe Mira de la început până la sfârșit: „Vai nouă, - totul e sfârșit! Eu nu! Eu nu! Manole, nu! Niciodată!” (LB 223). El neagă inițial faptul că $e l$ însuși ar fi putut face un asemenea lucru, ca apoi să rectifice: Manole, de fapt (înțeles ca soț al Mirei), nu ar fi putut-o zidi; eul, care este eul creator, ar fi capabil și chiar a făcut acest lucru. Manole, iubitul Mirei, într-adevăr a murit odată cu ea, însă Creatorul e încă viu. Mai mult, acea parte a eului a apus tocmai pentru viabilitatea şi împlinirea geniului creator. „Pe parcursul evoluției conflictului dramatic, Manole va înțelege că nu transcendenței va trebui să îi sacrifice sufletul, ci sie însuși. Pentru a deveni creator artist, va trebui să renunțe la postura de om, anume să confere alte valențe sufletului său. Iar sufletul său este Mira" (Bâgiu, Manole 227). Eroul lui Anania, în contrast cu cel blagian, e mai apropiat de postura mitică a creatorului: „Ceea ce deosebește fundamental poemul dramatic al lui Valeriu Anania de drama lui Blaga este tocmai temperarea gesturilor de răzvrătire ale meșterului, lipsa oricăror rezistențe la soluția sacrificiului, pe care el o determină și o impune fârtaților zidari, nu inconștiența pe durata sacrificiului, ci luciditatea extremă, suprasolicitarea, aproape inumană, a patimii creatoare, căreia îi cedează..." (Bâgiu, Valeriu Anania 266). Dacă în mit se remarcă un erou care poate fi definit drept artist, creator, la Blaga apare „omul creator” (Gană 361), la care datele umane joacă un rol primordial. În piesa lui 
Anania, Manole se situează undeva între aceste două ipostaze, fiind totuși preponderent integat ,în interiorul mitemului creației” (Bâgiu, Valeriu Anania 266).

După realizarea sacrificiului, ceea ce îi aseamănă pe meșterii din ambele piese este atitudinea lor față de sunet și față de amintiri. Ei devin hipersensibili la orice undă sonoră care le tulbură neantul interior și care ar putea interfera cu vaierul obsedant din zid: „Mai vorbește, dar încet că urechile mă dor de orice cuvânt. Și mâinile mele sunt reci, și am frig în mine, și nu pot saud cuvânt tare” (LB 214), „Să tacă! ... Doamne, n-am puteri/ Să mai aud un clopot. Prea mult ceri/ Sărmanei mele inimi!... Nu-i de-ajuns/ Că zi și noapte sufletul mi-e-mpuns/ De-arama rătăcită prin furtună?” (VA 178). Amintirile sunt chinuitoare, sfâsșietoare, sau, cum afirmă Safirin din opera lui Anania: „amintirea-i mai cumplită ca păcatul” (VA 102). La Blaga, Manole e cuprins într-un vârtej sufocant: „Amintiri - vin în goană ca o stavă neagră din șesul părăsit al vieții. Și trec, și nu se mai opresc. Și altele vin asurzitoare ridicând pulbere, că mă înec. Trupul stă și privește. Bine de cel ce poate vorbi. Încleștată rămâne gura suferinței pe rană” (LB 213). De aceea, poate, Manole are și pornirea de a distruge zidirea, înnebunit de durere: „Nimic nu mai vreau! Nimic! Totul să se dărâme! [...] Nu mai vreau minune, nu mai vreau nimic. Pe ea din piatră o vreau!” ( $L B$ 222), „Nu mai vreau ferestre, nu mai vreau turle, nu mai vreau nimic! Vaierul tot mai tare se aude. Gol și uitare să se lase în jurul nostru. Povestea noastră să se cufunde-n pământ, că a fost cea mai grea, cea mai tristă, mai fără de noimă, tulburătoare, din toate poveștile purtate vreodată de vânt" ( $L B$ 221). Același ecou ca în „,sunt beat și aș vrea să dărâm tot ce-i vis,/ ce e templu și-altar!” (Veniți după mine, tovarăși). Zadarnic, căci „omul încearcă să îl renege pe artistul din sine când deja acesta triumfase" (Bâgiu, Valeriu Anania 233).

Concluzia lui Manole e dureroasă și o spune suspinând, frânt: „,ce deșertăciune e în toate întocmirile!” ( $L B$ 228). În continuare, reiterând ideea că a fost doar un pion al jocului divinității, adaugă: „vreau în socoteala mea să se pună doar sugrumarea vieții, dar lăcaşul nu. Acesta Dumnezeu singur și l-a ridicat printr-o minune, pe care doar El o înţelege. Eu am fost numai o netrebnică unealtă, o scândură în schele pe care le dărâmi, când clădirea e gata și folosul vremelnic nu le mai cere. Așa suntem noi toți, unelte și scânduri în schele; unii-și dau seama mai curând, alţii mai târziu. Prin ceea ce din durere nimic nu ni se scade" ( $L B$ 228). Creatorul înțelege că, odată construcția încheiată, rolul lui s-a terminat: „,ceasul meu a încetat. Am dat ce am dat, orice dobândă e de prisos” ( $L B$ 232). Și Manole din piesa lui Anania îi spune voievodului - „Biserica-i gata, mândrețea-i fierbinte” (VA 205), semn că, odată realizată mănăstirea, înțelege sfârșitul menirii sale. Putem spune că această câștigare a autonomiei produsului creat este momentul în care mănăstirea 
se desprinde de creatorul ei, ajungând o operă cu valoare eternă: „Opera apare numai atunci când creatorul simte că lucrarea lui a atins un termen dincolo de care este inutil să mai continue și atunci când, în spațiul lumii, opera ocupă o poziție opusă creatorului său, creatorul privind din punctul său către punctul operei și luând cunoștință de ea ca de un lucru deosebit de sine” (Vianu 357).

De aici și până la înlăturarea „uneltelor” prin care s-a (de)săvârşit zidirea nu mai e decât un pas. În piesa blagiană, Manole se sinucide, mânat de propria-i durere. Blestemul a fost învins printr-un joc, i-am putea spune un joc secund, al creației. Cele două afirmații referitoare la el, rostite în această ordine de meșter în cronologia operei - „Jocul e scurt. Dar lungă și fără de sfârșit minunea” ( $L B$ 207). „Doamne, jocul a fost scurt, dar vaierul e lung” arată faptul că el conștientizează că a înfăptuit o creație minunată ce se integrează eternităţii, dar, pentru el, obsedant rămâne vaierul din ziduri. Pe Manole îl obsedează viața jertfită, nu opera înfăptuită (Bâgiu, Manole 234). Din această cauză, moartea lui poate fi înțeleasă fie literal, ca auto-pedeapsă și ca dorință de reunire cu Mira, fie în cheie simbolică, ca anihilare a creatorului de către creație, sau ca modalitate de a asigura desăvârșirea și durabilitatea acesteia.

Acesta din urmă este motivul sinuciderii meșterului din opera lui Anania. Trebuind să aleagă între dărâmarea zidirii și propria-i moarte, Manole alege sinuciderea. Îi spune voievodului: „... ai putere/ Să mă ucizi pe mine, dar nu-mi cere/ Să mi-o ucid!” (VA 215). Iubirea lui pentru acest lăcaș în care și-a îngropat iubirea și și-a mistuit patima creatoare e imensă, căci este de o frumusețe nemaipomenită. Sfetea admite forța hipnotizantă pe care o are construcția: „De mult, părinte, ne-am fi tot dus, care-ncotro,/ De nu ne-ar ține vraja mândreții ei de-a pururi./ O vezi? Făți ochii roată, fă sute de-nconjururi,/ Și-n marea frumusețe vezi mii de frumuseți./ C-ai scris-o, cai făcut-o, și tot mai vrei s-o-nveți,/ Dar numai de-o descoperi?” (VA 186). De aceea, când vodă dorește să afle motivul pentru care meșterii au ,zburat” de pe mănăstire, glasul ce stătea să se stingă în moarte al maestrului spune: „S-o ținem sus! De-acum/ N-o mai dărâmi!” (VA 224).

Pe lângă tumultul interior, se poate observa și antagonismul principial al creatorilor cu ceilalți oameni, care, cu puține excepții, nu le înțeleg esența menirii. De exemplu, vodă se îndoiește de reușita lor: „Vodă nu mai crede. Ați auzit zidari? Truda noastră nu mai găsește crezământ. Pentru alte încercări am mai găsi putere în noi, dar crezământ la alții nu” ( $L B$ 170). Ba mai mult, acesta îl consideră nebun, măscărici: „În trei zile, năstruşnic cum ești, o să-i tragi domnului o năzbâtie de Păcală. Dacă ești isteț, mai poți să ajungi ceva în viața asta nefolositoare, Manole. Vodă ar fi în stare să te facă nedisputată căpetenie peste zănatici și păcălici” ( $L B$ 172). În lupta lui cu stihiile, ceilalți zidari îl cred de asemenea nebun: „T,i-ai pierdut capul, Manole. Te repezi în moarte.”; „Un 
meșter are țara, și acela-i smintit!”; „Meșterul nostru e nebun” ( $L B$ 172). Tot astfel e văzut el de Iovanca în piesa lui Anania: „Da, zidirea nu-i curată. Sunt atâtea dulci păcate / Trecute printre pietre și atâta nebunie/ Strânsă-n mintea lui Manole..." (VA 117). La Blaga, meșterii îl acuză că ia ispitit cu „știință ascunsă și vrăjitorie” ( $L B$ 176). În orice caz, până biserica nu stă într-un final neclintită în faţa lor, ceilalți nu îl pot picta într-o lumină pozitivă pe creator (excepțiile fiind, bineînțeles, Mira și Simina). Când ajung însă la locul minunii fierbinți, laudele lor nu mai contenesc - ,în locul Măriei tale aș da afară din călindar un sfânt și-aș pune în locu-i numele lui Manole” ( $L B$ 229), ,asta-i tot așa de neîndoios o minune, pe cât sunt eu voievod” (LB 230), ,strașnic om Manole ăsta. Sufletul nu și-a cruțat, dar uite ispravă frate, pentru sute de ani!” ( $L B \quad 230)$, ,e cea mai frumoasă în toată credința Răsăritului” ( $L B$ 231) -, iar vodă încheie apoteotic, recunoscând superioritatea lui Manole în plan estetic: „,voi fi între slugile tale până la sfârșit” ( $L B$ 234). În acest plan al creațiilor artistice care se proiectează în veșnicie, raporturile ierarhice se inversează. Manole e „voievodul frumuseții”. Acest lucru este doar parțial înțeles de Neagoe în scrierea lui Anania. Superioritatea și puterea creatoare ale lui Manole îi rănesc orgoliul, de aceea poruncește urcarea zidarilor pe schele. Mai mult, pe el pare că-l obsedează nu atât frumusețea mănăstirii, cât omorul, pentru că „,miezul vieții/ Nu-i frumusețea, ci dreptatea” ( VA 214). Aceeași concepție o întâlnim și la boierii și la călugării din piesa blagiană: ,,a învins stihiile cu omor și fapta lui strigă la cer!”, ,,iată acesta e întâiul lăcaș al lui Anticrist”, ,auziți-l cum trage clopotul - cumplit și fără smerenie, parcă s-ar certa cu cerul!”, „trăind - ne batjocorește, trăind- va fi o primejdie...” ( $L B$ 236). Este atitudinea specifică mediocrității faţă de sublimul artei pe care n-o pot încadra în tiparele înguste ale minții lor. Invidia, ura și scopurile materiale primează, camuflându-se în spatele unor dorinţe de „dreptate”. Amenințarea genialității creatoare e prea mare pentru idealurile lor damnabile, de aceea cer moartea creatorului. La polul opus se situează însă mulțimea iubitoare de frumos, care ia partea lui Manole: „Nu, nu se poate! Meșterul neasemănat trebuie să trăiască!... Noi strigăm, boierii urlă, noi apărăm, călugării osândesc- toți suntem jos. Manole singur e sus, - singur deasupra noastră deasupra bisericii!" (LB 237). Aceste afirmații sunt edificatoare și dintr-un alt punct de vedere. Ele relevă pentru o ultimă dată diferența de planuri dintre înălţimea, sublimul și singurătatea geniului creator și josnicia, grotescul și sufocantul vârtej al celor mulți. Două lumi contrare pe care le unește creația, în dragoste sau ură, în viață sau în moarte.

Ceea ce îi individualizează cu adevărat pe acești doi creatori și ceea ce constituie de fapt filonul tragic al destinului lor este, așa cum se poate deduce privind în ansamblu operele, atitudinea lor faţă de iubire. În conștiința lor, ea se situează în același plan și la egalitate cu scopul creației: 
„Între voi două nicio deosebire nu fac, pentru mine sunteți una” ( $L B 154)$, „Că-n cumpăna de aur a cugetului meu/ Femeia se dă huța cu Domnul Dumnezeu” (VA 49). Drama sfâșierii creatorilor stă tocmai în această cumpănire între două lucruri la fel de importante, în care oricare din alegeri are consecințe catastrofale asupra lor. Această situație nu are o rezolvare viabilă: „Hei, meșteri mari, zidari, pietrari, se bat/ Războaie-ntre frumos și mai frumos,/ Războaie-ntre Adam și-ntre Hristos,/ Războaie-ntre luceferi și-ntre soare,/ Războaie-ntre femei și-ntre altare” (VA 142). Chiar dacă aceste războaie între entități la fel de însemnate și indispensabile sunt în cele din urmă câștigate de creație, victoria este, în realitate, o năruire. La un moment dat în piesa blagiană, văzând continuul pelerinaj al femeilor la mănăstirea care se ridica în urma jertfei, zidarii afirmă: ,toate-și închipuie cu înfricoșare că suntem mai tari decât iubirea noastră, dar aici lângă schelele înfăptuirei, se pare că ele înțeleg mai mult decât au putut să înțeleagă lângă vatră” (LB 211). E o ,,închipuire”, o aparență că ei au fost mai tari decât iubirea lor. Admirând spectacolul tragic al distrugerii umanului, privitorii își dau seama că în urma luptei fără câștigători între două pasiuni la fel de covârșitoare, omul creator nu poate fi decât învins, iar odihna lui nu poate fi atinsă decât în moarte.

Din toți acești „,muguri/ amari înfloresc (însă) potire grele de nectar” (Mugurii, Lucian Blaga). Chiar dacă ,înfăptuirea bisericii cere tot, și te duce de-a dreptul în moarte sau sărăcie, în cer sau nebunie” ( $L B$ 240), rezultatul ei rămâne peste veacuri. Acest fapt este oarecum compensația durerii fără margini și a frământărilor creatorilor. Nu rămâne nimic din zbucium în piatră, dar mănăstirea stă mărturie neclintită a eforturilor care au zidit-o. Cert este că ,,adeziunea unui popor la unul sau la altul dintre scenariile mitice, la una sau alta dintre imaginile exemplare, spune mai mult despre sufletul lui profund decât un mare număr de întâmplări istorice” (Eliade, De la Zamolxis 200). Pentru români, creația înseamnă suferință, sacrificiu, moarte și, nu în ultimul rând, minune. O minune înțeleasă nu în sensul ei religios, cât drept o operă a cărei frumusețe jertfelnică minunează și bucură în eternitate.

\section{Bibliografie:}

Anania, Valeriu. Meșterul Manole. București: Editura pentru Literatură, 1968.

---. Poeme. Iași: Polirom, 2010.

Bâgiu, Lucian-Vasile. Valeriu Anania. Scriitorul. Cluj-Napoca: Limes, 2006. 
---. „Manole” Def. la.Dicționarul personajelor din teatrul lui Lucian Blaga. Coord. Constantin Cubleșan. Cluj-Napoca: Dacia, 2005. 223-251.

Blaga, Lucian. Geneza metaforei și sensul culturii. București: Humanitas, 1994.

---. Meșterul Manole. București: Humanitas, 2008.

---. Poezii. Ediție îngrijită de Dorli Blaga. București: Editura Minerva, 1981.

Călinescu, George. Istoria literaturii române (compendiu). București: Litera Internațional, 2001.

Cubleșan, Constantin. Lucian Blaga. Zece ipostaze teatrale. Cluj-Napoca: Dacia XXI, 2011.

Eliade, Mircea. De la Zalmoxis la Genghis Han. București: Editura Humanitas, 1995.

---. Sacrul și profanul, București: Humanitas, 2000.

Gană, George. Opera literară a lui Lucian Blaga. București: Minerva, 1976.

Micu, Dumitru. Comentar la Meșterul Manole, în vol. Valeriu Anania, Greul pământului, vol. I. București: Eminescu, 1982. 223-234.

Todoran, Eugen. Lucian Blaga. Mitul dramatic. Timișoara: Facla, 1985.

Vianu, Tudor. Studii de filosofia culturii. București: Eminescu, 1982. 